\title{
Green Sustainable Human Resource Management in Malaysia
}

\author{
Eddy Prianto \\ (STIE Jaya Negara Tamansiswa Malang) \\ Clara Schneider \\ (Humboldt University of Berlin)
}

\begin{abstract}
The purpose of this study is to study environmentally friendly human resource management including employee behaviour in the workplace and the environment around the workplace. We used secondary data on 216 companies in Malaysia by conducting online interviews with 2160 employees about human resource and environmental management practices by quantifying them using the Likert scale and analyzing them using the ordinary least square model. We found a positive relationship between the level of environmental and social concern for the organization as reflected in environmentally friendly regulations and Standard Operating Procedures with human resource management as well as the level of employee compliance with company regulations and the level of employee welfare.
\end{abstract}

Keywords: Industry, Corporate Social Responsibility, Employees

\section{Background}

The environment and humans are a unity that should complement and protect each other. Where the environment is created to be empowered by humans. However, preserving the environment is a human obligation. Human resources are important resources in running a business and maintaining environmental and social sustainability. Human resources must be developed with knowledge and skills in order to be able to run a healthy business while protecting nature and the surrounding community (Yudanin,2020).

Nature provides useful materials for humans in the form of biological materials such as animals and plants and non-living materials such as mining goods. Nature provides good things for humans so that it is the duty of humans to protect nature. Nature that is awake provides continuous and sustainable good (Park \& Greenberg,2020). Humans can make use of nature so that it is beneficial for human interests. However, the use of nature that damages the environment will also be bad for humans. Caring for nature begins with an awareness of the importance of preserving nature and its benefits in protecting the environment.

Humans and nature can coexist and complement each other in life. Nature can continue to be used while maintaining natural sustainability. The existence of business activities in utilizing nature is important for human life to provide for human needs. However, preserving nature and preserving nature are also very important things too. 


\section{Literature Review}

The basic principle of this green economy is an effort to strengthen the risk management capacity of banks, particularly in relation to the environment and to encourage banks to increase their environmentally friendly financing portfolios, such as renewable energy, energy efficiency, organic agriculture and environmentally friendly transportation. By being involved in the development of an environmentally-based green economy, the banking sector is involved in efforts to promote more sustainable and inclusive growth to address gaps. A green economy is the enhancement of the quality of human life and social equity, while significantly reducing environmental risks and ecological scarcity. In its simplest terms, a green economy can be viewed as low carbon, resource efficiency and social inclusiveness (Akinsemolu,2020).

Environmental issues of sustainability and green organizations are increasingly being developed in management plans. This creates a green revolution (green revolution or environmentally friendly) in specific traditional ways, such as human resources. Recently in the field of Human Resources, the issue of Green Human Resource Management or what can be interpreted as "Environmentally Friendly Human Resource Management" has emerged which has identified itself as a new line of research and has become a new competitive dimension (Huque \& Zafarullah,2017).

Corporate environmental problems are complex, changing, and multifaceted. For example, there is a growing awareness of the implications of using plastics extensively in production systems for wildlife. Companies producing food packaging that rely on plastics as the main raw material may require complex knowledge of product redesign and new biodegradable materials to adapt company processes to less polluting raw materials. The problem is changing because, for a long time, plastic was considered a recyclable and more sustainable solution than other options. New evidence requires adaptation from both employers and employees. Finally, the problem is mixed because microplastics have implications for wildlife, but customers may also perceive the microplastics to come into contact with food, endangering their personal health. Approaching complex, changing and multifaceted environmental problems requires training, motivation and retention of a talented workforce (Susskind et al,2020).

Green management, with an emphasis on environmental protection, including conserving water, air, land, and the use of clean energy and renewable natural resources, will create significant opportunities for cost savings of goods and services and reduce negative and damaging effects on the environment. Nowadays, employees tend to work in such companies and feel happy because they are environmentally friendly. Furthermore, the company's strategy for environmental management and sustainable development will be successful if it is in line with its HR practices (Yang,2017).

\section{Research Methods}

This study examines the impact of business management, employee income, the level of employee compliance with company regulations on environmental sustainability around the company using the Ordinary Least Squares (OLS) method with the following equation :

$\mathrm{ES}_{\mathrm{t}}=\mathrm{C}_{\mathrm{t}}+\beta_{1} \mathrm{Bm}_{\mathrm{t} 1}+\beta_{2} \mathrm{Ei}_{2}+\beta_{3} \mathrm{Ec}_{\mathrm{t} 3}+\mathrm{e}_{\mathrm{t}}$

Where, 
$\mathrm{ES}=$ Environmental Sustainability

$\mathrm{Bm}=$ Business Management

$\mathrm{Ei}=$ Employee Income

$\mathrm{Ec}=$ Employee Compliance

$\mathrm{e}=$ The term error

Business management in this study is a management factor calculated based on the results of interviews about the level of environmentally friendly business management and seeing the impact of business on the environment using the Likert scale to quantify the results of the interview. Environmental sustainability is calculated by comparing the condition of the environment before the business or company was founded with environmental changes due to company activities within a certain period of time using a Likert scale to quantify the results of the interview. Employee income is a reflection of the employee's welfare by adding up salaries and bonuses as well as other income obtained from the company which is compared with the minimum wage in the area of each area where he works and his family live so that a fair comparison is obtained for each. sample of employees even though they have different operational areas working in Malaysia. Employee compliance is a quantification of the employee management level Likert scale against the company's standard operating rules and procedures.

\section{Results and Discussion}

The estimation results are as follows:

$\mathrm{ES}=0.231421+0.402161 * \mathrm{Bm}+0.321425 * \mathrm{Ei}+0.223614 * \mathrm{Ec}$

From the OLS estimation results, business management has an effect on environmental sustainability of 0.402161. If Business Management increases by 1\%, then Environmental Sustainability will increase by $0.413172 \%$. Employee income and employee compliance have a positive effect on environmental sustainability. Table 1 illustrates the estimation results as follows:

Table 1. Estimation Results

\begin{tabular}{|l|l|l|l|}
\hline Dependent variable ES & Coefficient & t-Statistic & Prob. \\
\hline Variable & 0.231421 & 0.101781 & 0.0004 \\
\hline $\mathrm{C}$ & 0.402161 & 0.121491 & 0.0015 \\
\hline $\mathrm{Bm}$ & 0.321425 & 0.120189 & 0.0012 \\
\hline $\mathrm{Ei}$ & 0.223614 & 0.112460 & 0.0018 \\
\hline $\mathrm{Ec}$ & 0.850301 & Mean dependent var & 2.18131 \\
\hline R-squared & 0.862161 & S.D. dependent var & 4.13021 \\
\hline Adjusted R-squared & 1.0130 & Sum squared resid & 2.21173 \\
\hline S.E. of regression & 1.1211 & Durbin-Watson stat & 0.41421 \\
\hline F-statistic & 0 & & \\
\hline Prob(F-statistic) & & \\
\hline
\end{tabular}

Based on the estimation results described in Table 1. This shows that the level of environmental sustainability is influenced by business management, employee welfare, and the level of employee compliance with company regulations. Where the level of environmental concern in business activities needs to be owned by all employees so that nature remains sustainable. 


\section{Conclusion}

Environmental care is an awareness that needs to be instilled so that business activities can be managed without damaging the environment and preserving nature in Malaysia. A sustainable nature will provide well for all humans so that humans can live well. Malaysia is a large country with abundant natural wealth. Green human resource management is important in Malaysia because the preservation of nature has an impact on the Malaysian economy.

\section{Reference :}

Akinsemolu,A.A.(2020).The Principles of Green and Sustainability Science. Cham : Springer

Huque,A,S., Zafarullah,H.(2017).International Development Governance. London: Routledge

Park,T.K, Greenberg,J.B. (2020).Terrestrial Transformations: A Political Ecology Approach to Society and Nature.Lanham : Rowman \& Littlefield

Susskind,L., Verdini,B, Gordon,J.(2020).Environmental Problem-Solving: Balancing Science and Politics Using Consensus Building Tools. London: Anthem Press.

Yang,J.(2017).Environmental Management in Mega Construction Projects.Cham : Springer

Yudanin,M.(2020).Animal Choice and Human Freedom: On the Genealogy of Self-determined Action. Lanham : Rowman \& Littlefield 